\title{
EVIDENCE FOR GENERAL DISTRIBUTION OF PERIPHERAL RESISTANCE IN COARCTATION OF THE AORTA: REPORT OF THREE CASES
}

\author{
By J. MURRAY STEELE \\ (From the Hospital of the Rockefeller Institute for Medical Research, New York City)
}

(Received for publication April 24, 1941)

The frequency with which elevation of arterial pressure attends stenosis (coarctation) of the arch of the aorta was first made clear several years ago by Lewis (1), and has recently been emphasized by King (2) in a complete review of cases in which estimations of arterial pressure have been made. King agrees essentially with Lewis when he says, "Hence, there is no well defined case so far recorded in which the circulatory compensation was above suspicion and in which the pressure in both arms was found to be normal." In this statement the upper limit of normal systolic pressure is taken to be 140 and diastolic, $100 \mathrm{~mm}$. $\mathrm{Hg}$.

Various explanations have been advanced to account for hypertension in the arms which occurs with such regularity in association with coarctation of the aorta. Blumgart, Lawrence and Ernstene (3) ascribed the hypertension to the resistance furnished by the constriction of the aorta and by the collateral passages. They held this view chiefly because arteriolar pressure in the upper extremities was found to be normal.

From studies of blood flow in the hand and upper arm, Prinzmetal and Wilson (4) and Pickering (5) came independently and almost simultaneously to conclusions which differed from the earlier notions of Blumgart and his co-workers. Both authors found that there was an increase in resistance to the flow in the upper extremities which was of general distribution, but they were unable to agree upon the mechanism by which the increase was brought about. Prinzmetal and Wilson believed that the increase in arteriolar tone was due to hyperactivity of the vasomotor nerves for, when the vasoconstrictor activity was inhibited by application of heat, the increase in the flow of blood through the hand was found to be much greater than in normal individuals or in individuals suffering from " essential " hypertension. The results of Pickering's studies were in accord with
Prinzmetal and Wilson so far as general distribution of increased resistance was concerned. Pickering was, however, unable to show any greater increase in flow of blood than that encountered in normal individuals either when heat was applied to the arm or when the nerves of the extremities had been injected with novocain. Evidence for the existence of nervous origin of the arteriolar hypertonus was lacking in his experiments. He pointed out that there were no known nervous pathways which could lead stimuli to affect only the vasomotor system in the upper half of the body and that the view that a substance circulating in the blood could give rise to contraction of the vessels in the upper half of the body only was likewise untenable. He suggested tentatively that some abnormality of the peripheral arterioles-such as hypoplasia of the glomi-might explain an increase in resistance in the upper extremities. This notion avoided the necessity of inferring an increase in tone confined to the arterioles of the upper half of the body.

Conclusions from these studies were drawn under the assumption that increased resistance was present only in the upper half of the body in coarctation of the aorta. When the facts upon which this assumption rests are more closely examined, it becomes evident that they are insufficient. First, the importance of diastolic pressure in drawing conclusions concerning peripheral resistance has not been recognized. A clear distinction between increase in peripheral or arteriolar resistance and increase in elastic resistance, due in coarctation of the aorta mainly to decrease in size of the arterial reservoir, needs to be made. For measuring peripheral resistance, diastolic, not systolic pressure is important. Second, measurements of pressure in the legs carried out by the auscultatory technique with pneumatic cuffs of a size suitable for arms, often in the presence of admittedly feeble Korotkow sounds, cannot be con- 
sidered reliable enough to show with any degree of certainty that either level of arterial pressure is high, low or normal in the lower half of the body. Third, the number of satisfactory observations upon arterial pressure in the legs are too few.

The inadequacy of the information so far available made it desirable to describe direct simultaneous records of arterial pressure in radial and femoral arteries of three cases of coarctation of the aorta. The records were obtained by use of two Hamilton intra-arterial manometers. All three cases exhibited marked hypertension in the upper extremities and also many of the symptoms so frequently observed in instances of " essential " hypertension, such as emotional instability, headache and easily induced fatigue. Two of the cases were classified for several years in more than one clinic as " essential" hypertension.

Case $1.1 W$. G. A white male clerk, aged 30 , was first seen at the hospital of the Rockefeller Institute on January 27th, 1936. He had always been nervous and moody and had been told at 10 years of age that he had high blood pressure. At 21 years of age he began to notice palpitation and mild precordial pain on effort and with excitement and headache. On examination the sounds of the heart were distinct, the rate regular but rapid and a loud systolic murmur was always present in the third right interspace. The walls of the radial arteries were readily palpable but elasticity as inferred from measurements of the velocity of the arterial pulse wave in the brachio-radial artery (6.4 meters per second) was within the range of normal. Brachial arterial pressure was very variable $(170 / 96$ to $230 / 130$; on one occasion, 280/170). The pressure in the legs was not easily measured by auscultatory technique; it was, roughly, $120 / 100$ with a pneumatic cuff $20 \mathrm{~cm}$. wide. There were well-marked subscapular pulsations and murmurs. The femoral pulse was scarcely palpable. Renal function was normal, the basal metabolic rate varied between +6 and +15 per cent. Dr. Harold J. Stewart (Case 5, Stewart's (30) series) found his cardiac output to be 2.85 liters per square meter per minute, a moderate increase. At that time (September 1939) the basal metabolic rate was +25 per cent. X-ray photographs of the chest showed the notching of the ribs described by Railsbeck and Dock (6), and constriction of the aorta was visible. On fluoroscopic examination there was little or no pulsation below the constriction, while above it was very vigorous.

This patient is at present fairly well and working regularly as clerk-foreman. He complains still of fatigue, occasional palpitation and nervousness. His arterial pressure remains in the neighborhood of $220 / 120$ $\mathrm{mm}$. $\mathrm{Hg}$.

1 Cases 1 and 3 were kindly referred by Dr. William Goldring of New York University Medical School.
Case 2. H. L. A married woman, aged 46 at death on June 31st, 1939, came to this hospital November 14th, 1922 complaining of headache and dizziness. She stated that arterial hypertension had been discovered one year previously. She was followed at rather frequent intervals throughout the remainder of her life. Until the appearance of signs of heart failure in 1937, she was quite well. Renal function was always good. Pulsations were present over the lower part of the chest posteriorly. The femoral pulse was just palpable. Arterial pressures measured by the auscultatory technique in the brachial artery varied between 210 and $260 \mathrm{~mm}$. $\mathrm{Hg}$ systolic, 120 and 180 diastolic; and in either leg between 100/96 and $120 / 100$. The measurements in the legs were made with a wide cuff. X-ray photographs of the thorax exhibited the characteristic notching of the ribs from 1922 on. In May 1938 a right-sided hemiplegia occurred. She suffered an attack of lobar pneumonia in January 1939 and died six months later following what was apparently a cerebral vascular accident.

Postmortem showed a marked constriction of the aorta just above and at the level of the origin of the renal vessels. The lumen was reduced to about $2 \mathrm{~mm}$. in diameter. The nature of the constriction is not yet clear. ${ }^{2}$

Case 3. A. C. A healthy youth, aged 16 , was referred to this hospital for study on March 1st, 1939 because hypertension discovered a few months earlier on examination for working papers had lead to the diagnosis of coarctation of the aorta. His only complaints were that he became a little short of breath running with other boys and that he frequently had cramps in his legs at night after long walks (8- to 10-mile hikes).

He was a large-framed, healthy looking lad. The radial pulse was full and bounding. Pressure in either brachial artery varied between 170 and $200 \mathrm{~mm}$. $\mathrm{Hg}$ systolic, 100 and $108 \mathrm{~mm}$. $\mathrm{Hg}$ diastolic. The sounds of the heart were essentially normal. On both sides of the chest, between the lower part of the scapulae and spine, deep strong arterial pulsations were seen and felt. The femoral pulses were barely palpable; popliteal and pedal pulses were not felt. Measurements of arterial pressures in the leg with two sizes of cuff placed just above the knee were unsatisfactory. With a $20 \mathrm{~cm}$. cuff, systolic pressure was estimated at 116, diastolic at 104; with a $12.5 \mathrm{~cm}$. cuff, systolic and diastolic pressures were estimated at 120 and 108 , respectively.

The circulation time was measured on two occasions by intravenous injections of a solution of magnesium sulphate and calcium gluconate (7). Fair agreement was obtained between the two measurements (Table I). It is of interest to note that on both occasions two distinct waves of heat were felt in the crotch, suggesting that part of the blood may have reached the perineum through the aorta and part through the collateral circulation.

The patient continues to attend school and leads an apparently normal life free of symptoms.

2 This location of aortic constriction is distinctly rare. A detailed report of the case will appear elsewhere. 


\section{TABLE I}

Velocity of flow of blood (Case 3) measured by injection of a solution of calcium gluconate and magnesium sulphate on two occasions

\begin{tabular}{c|c|c|c|c|c|c}
\hline Test & $\begin{array}{c}\text { Face } \\
\text { Tongue }\end{array}$ & Chest & Arm & Hand & Crotch & $\begin{array}{c}\text { Leg } \\
\text { (Thigh })\end{array}$ \\
\hline 1 & 12 & 14 & 18 & & $\begin{array}{c}20 \\
\text { and } \\
31\end{array}$ & 24 \\
\hline 2 & 12 & 17 & 21 & 24 & $\begin{array}{c}22 \\
\text { and } \\
29\end{array}$ & 26 \\
\hline
\end{tabular}

Figures record in seconds the time of arrival of the sensation of heat at the various points indicated. Note the occurrence of sensation of heat twice in the perineal region (crotch).

\section{DISCUSSION}

The valuable collection of material by King has made it a simple matter to bring up to date the facts known about the levels of arterial pressure in cases of coarctation. King collected 175 cases in which blood pressure measurements had been made and since that time forty-two have been reported, making a total of 217 (Table II) (8 to 26). As King points out, practically all exhibit elevation of systolic pressure in at least one arm (Table III). Since the state of peripheral resistance is the chief concern of the present discussion, it is important also to note that elevation of diastolic pressure (above $100 \mathrm{~mm} . \mathrm{Hg}$ ) in at least one arm was present in nearly half of the number of cases in which it was measured (Table III). Diastolic pressure in the legs was recorded in only sixtyfive cases, and in about one-fifth (twelve cases), in spite of very small pulse pressures, it was above $100 \mathrm{~mm}$. Hg. In four, it was higher in the legs than in the arms. It is plain, too, from frequent statements of the difficulty encountered in recording pressure in the legs by means of a pneumatic cuff and auscultation that these measurements may not be reliable. Even so, elevation of the diastolic pressure in the legs (and inferentially, increase in peripheral resistance) seems to be not altogether infrequent and the assumption that increase in peripheral resistance is confined to the upper half of the body does not appear to be warranted.

In the present study, direct simultaneous measurements of the levels of arterial pressure in radial and femoral arteries of the three cases of coarctation of the aorta just described were obtained by the use of two intra-arterial manometers (27). Pressures recorded from the radial arteries of normal and hypertensive individuals in this manner differ but little from those recorded for the femoral, especially with regard to diastolic pressure. Systolic is usually slightly higher in the femoral. In indirect measurements, if a larger cuff is used for the legs $(20 \mathrm{~cm}$.) than for the arms $(12 \mathrm{~cm}$.), the agreement between these measurements and those obtained from the intra-arterial manometers is better than with a small cuff, but is still not satisfactory. The use of both methods (intraarterial manometers and auscultatory technique with a large cuff) demonstrates that the diastolic pressure is roughly the same in the femoral as in the radial artery in both normal and hypertensive individuals.

The diastolic level of arterial pressure in the radial arteries was found, by direct measurement to be elevated in all three cases. The diastolic pressure in the femoral artery was above $100 \mathrm{~mm}$. $\mathrm{Hg}$ in two cases (Figure 1, Case 1 and Figure 2, Case 3 ). In the case in which the diastolic pressure was below $100 \mathrm{~mm} . \mathrm{Hg}$ in the legs (Figure 2, Case 2), not only a slight narrowing of the aorta in the region of the isthmus but almost complete occlusion just above the renal vessels was found on autopsy. This case is all the more interesting because of the great height of both levels of pressure in the arms. It was by clamping the aorta in this region, just above the renal arteries, that Page (28) was able to obtain the greatest elevation of pressure. The failure of the pressure to become elevated in the legs was probably due to the marked degree and the unusually low site of the constriction. Yet, with a pulse pressure of only $15 \mathrm{~mm}$. $\mathrm{Hg}$, the diastolic pressure in the legs remained above $90 \mathrm{~mm}$. Pulse pressure and systolic pressure were, as can readily be seen in the tracings, much smaller in the femoral than in the radial artery in all three cases.

Study of a case of coarctation of the aorta by means of direct measurement of arterial pulse pressure was published by Woodbury, Murphey and Hamilton (29) while preparation of this manuscript was in progress. Their study includes a number of clear-cut detailed observations upon the dynamics of the circulation. It is important to note that these authors find only small differences between diastolic pressure in femoral and 
TABLE II

Cases of coarctation of the aorta reported in the literature since 1937

\begin{tabular}{|c|c|c|c|c|c|c|c|}
\hline \multirow{2}{*}{ Number } & \multirow{2}{*}{ Author } & \multirow{2}{*}{ Sex } & \multirow{2}{*}{ Age } & \multicolumn{2}{|c|}{ Blood pressure } & \multirow{2}{*}{ Color } & \multirow{2}{*}{ Autopsy } \\
\hline & & & & Arm & Leg & & \\
\hline 1 & $\begin{array}{l}\text { Appelbaum, E., and Kalk- } \\
\text { stein, M. }\end{array}$ & M. & 38 & $\begin{array}{l}\text { R. } 180 / 130 \\
\text { L. } 240 / 114\end{array}$ & $\begin{array}{l}\text { Oscillometer } \\
\text { reading 150/100 }\end{array}$ & W. & No \\
\hline 2 & $\begin{array}{l}\text { Barsantini, J. C., and Baz- } \\
\text { zano, J. J. }\end{array}$ & M. & 24 & $\begin{array}{l}\text { R. } 165 / 100 \\
\text { L. } 170 / 100\end{array}$ & & W. & Yes \\
\hline 3 & $\begin{array}{l}\text { Benkowitz, K. B., and } \\
\text { Hunter, W. C. }\end{array}$ & M. & 67 & $\begin{array}{l}\text { R. } 180 / 85 \\
\text { L. } 180 / 80\end{array}$ & & $?$ & Yes \\
\hline 4 & Gitlow, S. & M. & 26 & $\begin{array}{l}152 / 90 \\
160 / 100 \\
\end{array}$ & 123 by palpation & W. & No \\
\hline 5 & Goodson, W. H. & M. & $16 \frac{1}{2}$ & $\frac{150}{90}$ (average) & $\frac{110}{90}$ & W. & Yes \\
\hline 6 & Goodson, W. H. & F. & 19 & $\begin{array}{l}\text { R. } 164 / 92 \\
\text { L. } 152 / 80\end{array}$ & $\begin{array}{l}\text { Could not be } \\
\text { read }\end{array}$ & W. & No \\
\hline 7 & Hills, R. G. & M. & 16 & $\begin{array}{l}\text { R. } 180 / 100 \\
\text { L. } 110 / 85\end{array}$ & $110 / 90$ & W. & No \\
\hline 8 & Klemola, E. & M. & 27 & $220 / 110$ & $?$ & W. & No \\
\hline 9 & Klemola, E. & M. & 20 & $\begin{array}{l}\text { R. } \frac{160-165}{80} \\
\text { L. } \frac{145-155}{80}\end{array}$ & $\begin{array}{l}\text { R. } \frac{125-135}{80} \\
\text { L. } 135 / 80\end{array}$ & W. & No \\
\hline 10 & Klemola, E. & M. & 19 & $200 / 100$ & $?$ & W. & No \\
\hline 11 & Klemola, E. & $?$ & 22 & $140 / 90$ & & W. & No \\
\hline 12 & McNair, J. S. & M. & 11 & $154 / ?$ & $90 / 70$ & $?$ & No \\
\hline 13 & $\begin{array}{l}\text { Parker, R. L., and Dry, } \\
\text { T. J. }\end{array}$ & M. & 26 & $\begin{array}{l}\text { R. } 210 / 40 \\
\text { L. } 100 / 78\end{array}$ & No pulse feit & $?$ & Yes \\
\hline 14 & $\begin{array}{l}\text { Regester, R. P., and Innes, } \\
\text { M. B. }\end{array}$ & M. & 19 & $\begin{array}{l}\text { R. } 190 / 150 \text { to } 190 / 124 \\
\text { L. } 130 / 90\end{array}$ & Not taken & W. & Yes \\
\hline 15 & $\begin{array}{c}\text { Ernstene, A. C., and } \\
\text { Robins; S. A. }\end{array}$ & M. & 47 & $164 / 94$ & $86 / 76$ & W. & No \\
\hline 16 & Rooke, E. J. & M. & 3 & $\begin{array}{l}\text { R. } 150 / 85 \\
\text { L. } 110 / ? \\
1 \text { month later } 162 / ?\end{array}$ & Not taken & W. & No \\
\hline 17 & Sheldon, W. & M. & 12 & $150 / 100$ & No pulse & W. & No \\
\hline 18 & Steele, J. M. & M. & 29 & $\begin{array}{l}\text { R. } 170 / 98 \\
\text { R. } 230 / 130\end{array}$ & R. $120 / 100$ & w. & No \\
\hline 19 & Steele, J. M. & F. & 45 & $\begin{array}{l}\text { R. } 170 / 120 \\
\text { R. } 282 / 168 \\
\end{array}$ & $\begin{array}{r}\text { R. } 100 / 94 \\
120 / 98 \\
\end{array}$ & W. & Yes \\
\hline 20 & Steele, J. M. & $\mathbf{M}$. & 16 & $\begin{array}{l}\text { R. } 170 / 96 \\
\text { R. 200/108 } \\
\end{array}$ & R. $120 / 108$ & W. & No \\
\hline 21 & Venzoni, $\mathbf{M}$. & M. & 24 & $200 / 120$ & & W. & Yes \\
\hline 22 & $\begin{array}{l}\text { Walker, J. B., and Living- } \\
\text { stone, F. D. M. }\end{array}$ & M. & 17 & $\begin{array}{l}178 / 100 \\
215 / 110\end{array}$ & $110 / 90$ & W. & Yes \\
\hline
\end{tabular}


TABLE II-Continued

\begin{tabular}{|c|c|c|c|c|c|c|c|}
\hline \multirow{2}{*}{ Number } & \multirow{2}{*}{ Author } & \multirow{2}{*}{ Sex } & \multirow{2}{*}{ Age } & \multicolumn{2}{|c|}{ Blood pressure } & \multirow{2}{*}{ Color } & \multirow{2}{*}{ Autopsy } \\
\hline & & & & Arm & Leg & & \\
\hline 23 & $\underset{\text { Gustafson, E. }}{\text { Wechisler, }}$ & M. & 30 & $\begin{array}{l}\text { R. } 160 / 50 \\
\text { L. } 190 / 56\end{array}$ & $\begin{array}{l}\text { R. } 180 / 80 \\
\text { L. } 104 / 80\end{array}$ & w. & Yes \\
\hline 24 & 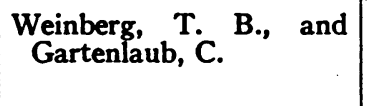 & M. & 23 & $\begin{array}{l}\text { R. } 150 / 90 \\
\text { to } 170 / 90 \\
\text { L. } 100 / 90\end{array}$ & Not obtainable & w. & No \\
\hline 25 & $\begin{array}{l}\text { Weinberg, T. T., and } \\
\text { Gartenlaub, C. }\end{array}$ & F. & 41 & $\begin{array}{l}\text { R. } 200 / 76 \\
\text { L. } 194 / 72\end{array}$ & $\begin{array}{l}\text { R. } 94 / 80 \\
\text { L. } 92 / 76\end{array}$ & $?$ & $?$ \\
\hline 26 & Wilkinson, K. D. & F. & 5 & $150 / 80$ & Feeble pulse & w. & No \\
\hline 27 & Wilkinson, K. D. & M. & 14 & $198 / 135$ & No pulse & w. & No \\
\hline 28 & Wolke, $\mathrm{K}$. & F. & 38 & $\begin{array}{l}210 / 105 \\
210 / 110\end{array}$ & Unsatisfactory & W. & No \\
\hline 29 & Wolke, $\mathrm{K}$. & F. & 36 & $\begin{array}{l}\text { R. } 160 / 100 \\
\text { L. } 160 / 100 \\
\end{array}$ & Unsatisfactory & W. & No \\
\hline 30 & $\begin{array}{l}\text { Woodbury, R. A., Mur- } \\
\text { phey, E. E., and Hamil- } \\
\text { ton, W. F. }\end{array}$ & M. & 26 & $164 / 100$ & $130 / 100$ & W. & No \\
\hline 31 & $\begin{array}{l}\text { Stewart, H. J., and Bailey, } \\
\text { R. L. }\end{array}$ & $?$ & 15 & $\begin{array}{l}\text { R. } 170 / 90 \\
\text { L. } 160 / 87\end{array}$ & $\begin{array}{l}\text { R. } 100 / 80 \\
\text { L. } 95 / 90\end{array}$ & W. & No \\
\hline 32 & $\begin{array}{l}\text { Stewart, H. J., and Bailey, } \\
\text { R. L. }\end{array}$ & $?$ & 28 & $\begin{array}{l}\text { R. } 136 / 70 \\
\text { L. } 134 / 72\end{array}$ & $\begin{array}{l}\text { R. } 120 / 90 \\
\text { L. } 115 / 90\end{array}$ & $\mathbf{w}$. & No \\
\hline 33 & $\begin{array}{l}\text { Stewart, H. J., and Bailey, } \\
\text { H. L. }\end{array}$ & $?$ & 23 & $\begin{array}{l}\text { R. } 174 / 60 \\
\text { L. } 134 / 72\end{array}$ & $\begin{array}{l}\text { R. } 98 / 82 \\
\text { L. } 96 / 84\end{array}$ & W. & Yes \\
\hline 34 & $\begin{array}{l}\text { Stewart, H. J., and Bailey, } \\
\text { R. L. }\end{array}$ & $?$ & 9 & $\begin{array}{l}\text { R. } 200 / 120 \\
\text { L. } 195 / 120\end{array}$ & $\begin{array}{l}\text { R. } 125 / 105 \\
\text { L. } 150 / 145\end{array}$ & W. & No \\
\hline 35 & $\begin{array}{l}\text { Stewart, H. J., and Bailey, } \\
\text { R. L. }\end{array}$ & $?$ & 38 & $\begin{array}{l}\text { R. } 165 / 110 \\
\text { L. } 180 / 110\end{array}$ & $\begin{array}{l}\text { R. Not } \\
\text { L. obtainable }\end{array}$ & W. & No \\
\hline 36 & $\begin{array}{l}\text { Stewart, H. J., and Bailey, } \\
\text { R. L. }\end{array}$ & $?$ & 64 & $\begin{array}{l}\text { R. } 200 / 100 \\
\text { L. } 190 / 90\end{array}$ & $\begin{array}{l}\text { R. Not } \\
\text { L. obtainable }\end{array}$ & W. & Yes \\
\hline 37 & $\begin{array}{l}\text { Stewart, H. J., and Bailey, } \\
\text { R. L. }\end{array}$ & $?$ & 22 & $\begin{array}{l}\text { R. } 160 / 86 \\
\text { L. } 160 / 80\end{array}$ & $\begin{array}{l}\text { R. } 110 / 80 \\
\text { L. } 108 / 80\end{array}$ & W. & No \\
\hline 38 & $\begin{array}{l}\text { Stewart, H. J., and Bailey, } \\
\text { R. L. }\end{array}$ & $?$ & 27 & $\begin{array}{l}\text { R. } 200 / 100 \\
\text { L. } 230 / 130\end{array}$ & $\begin{array}{l}\text { R. } 125 / 110 \\
\text { L. } 125 / 110\end{array}$ & W. & No \\
\hline$* 39$ & $\begin{array}{l}\text { Stewart, H. J., and Bailey, } \\
\text { R. L. }\end{array}$ & $?$ & 48 & $\begin{array}{l}\text { R. } 255 / 160 \\
\text { L. } 240 / 160\end{array}$ & L. $290 / 200$ & W. & Yes \\
\hline 40 & $\begin{array}{l}\text { Stewart, H. J., and Bailey, } \\
\text { R. L. }\end{array}$ & $?$ & 16 & $\begin{array}{l}\text { R. } 168 / 80 \\
\text { L. } 138 / 80 \\
\end{array}$ & \begin{tabular}{|l|} 
R. Not \\
L. obtainable \\
\end{tabular} & W. & Yes \\
\hline 41 & $\begin{array}{l}\text { Stewart, H. J., and Bailey, } \\
\text { R. L. }\end{array}$ & $?$ & 24 & $\begin{array}{l}\text { R. } 220 / 120 \\
\text { L. } 180 / 120\end{array}$ & $\begin{array}{l}\text { R. } 120 / 98 \\
\text { L. } 108 / 100\end{array}$ & W. & Yes \\
\hline 42 & $\begin{array}{l}\text { Stewart, H. J., and Bailey, } \\
\text { R. L. }\end{array}$ & $?$ & 26 & $\begin{array}{l}\text { R. } 170 / 70 \\
\text { L. } 170 / 70\end{array}$ & $\begin{array}{l}\text { R. Not } \\
\text { L. obtainable }\end{array}$ & W. & No \\
\hline
\end{tabular}

Cases are listed in a manner comparable to that employed in King's paper.

* This patient did not have coarctation sufficient to produce any obvious alterations in the hemodynamics of the circulation. 
TABLE III

Frequency of elevation of levels of arterial pressure in cases of coarctation of aorta

\begin{tabular}{|c|c|c|c|}
\hline & $\begin{array}{l}\text { Total } \\
\text { num- } \\
\text { ber } \\
\text { cases }\end{array}$ & $\begin{array}{l}\text { Num- } \\
\text { ber } \\
\text { ele- } \\
\text { vated* }\end{array}$ & $\begin{array}{l}\text { Per } \\
\text { cent } \\
\text { ele- } \\
\text { vated }\end{array}$ \\
\hline $\begin{array}{l}\text { Cases with measurements of systolic pressure } \\
\text { In at least one arm } \ldots \ldots \ldots \ldots \ldots \ldots \ldots \ldots \ldots \\
\text { In at least one leg. } \ldots \ldots \ldots \ldots \ldots \ldots \ldots\end{array}$ & $\underset{98}{216 \dagger}$ & $\begin{array}{r}195 \\
10\end{array}$ & $\begin{array}{l}90 . \\
10 .\end{array}$ \\
\hline $\begin{array}{l}\text { Cases with measurements of diastolic pressure } \\
\text { In at least one arm } \ldots \ldots \ldots \ldots \ldots \ldots \ldots \ldots \ldots \\
\text { In at least one leg } \ldots \ldots \ldots \ldots \ldots \ldots \ldots \ldots\end{array}$ & $\begin{array}{r}194 \\
73\end{array}$ & $\begin{array}{l}86 \\
16\end{array}$ & $\begin{array}{l}44.2 \\
22 .\end{array}$ \\
\hline
\end{tabular}

* Pressures above $140 \mathrm{~mm}$. $\mathrm{Hg}$ systolic and $100 \mathrm{~mm} . \mathrm{Hg}$ diastolic were considered elevated.

t One case (Number 39, Table II) was omitted since the degree of coarctation was so slight as to be insignificant in disturbing hemodynamic relationships and also because well-marked renal lesions were present at autopsy.

radial arteries -88 in the arm and 82 in the leg. These values for diastolic pressure are not indicative of an increase in peripheral resistance either above or below the coarctation but their close agreement suggests that peripheral resistance above the coarctation does not differ from that encountered below it. On several occasions, however, high values for diastolic pressures, both above and below the coarctation, were recorded during control periods (radial artery 111, dorsalis

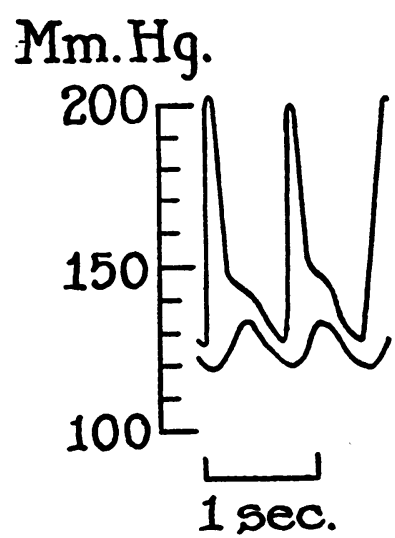

Fig. 1. Simultaneous Tracings of Arterial Pressure from the Femoral and Radial Arteries (Case 1) Redrawn to the Same Scale Illustrate the Difference in Pulse Pressure

pedis $98 \mathrm{~mm} . \mathrm{Hg}$; radial artery 121, dorsalis pedis $110 \mathrm{~mm} . \mathrm{Hg}$ ). Such high levels are rarely encountered in normal persons and suggest that unusual increases in peripheral resistance were not infrequent in this individual.

It is plain that in coarctation of the aorta, in spite of a very low systolic pressure in the legs, a level of diastolic pressure comparable to that
$\mathrm{Mm} . \mathrm{Hg}$

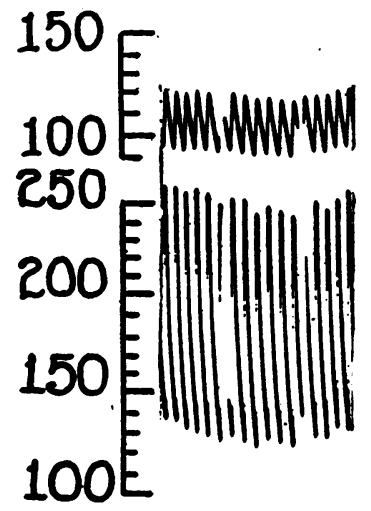

\section{Mm. Hg}

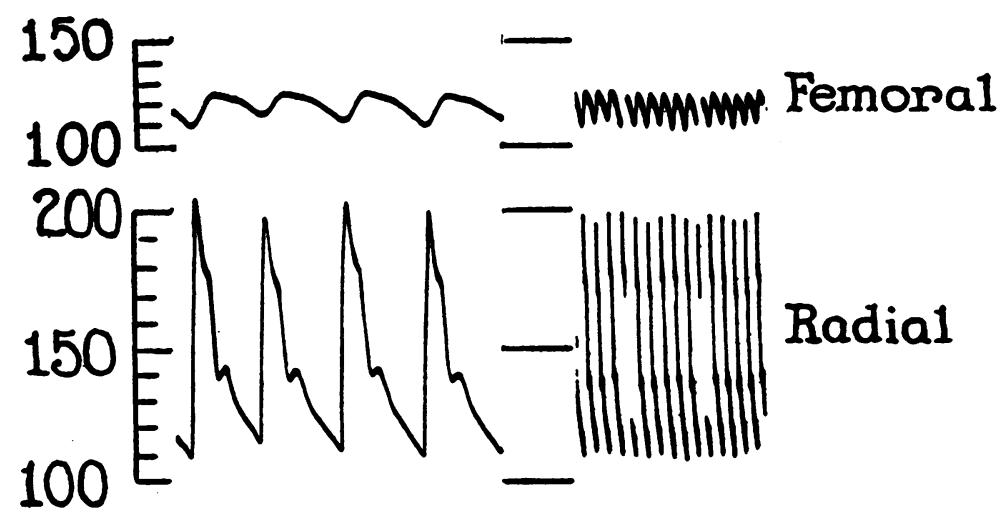

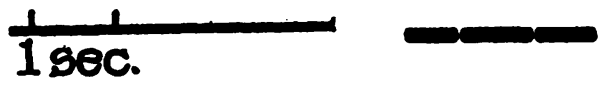

Case 2

\section{Case 3}

Fig. 2. Simultaneous Photographic Records of Arterial Pressure in the Radial and Femoral Arteries of Two Cases of Coarctation of the Aorta (Cases 2 and 3) Are Reproduced 
in the arms often exists. Increase in cardiac output does not ordinarily account for the great increase in pressure which is frequently observed (30), although cardiac output may sometimes be large enough, as in one of Stewart's cases (30), to account for mild rises in arterial pressure. These observations, together with the knowledge that the flow of blood in the legs is no greater than normal $(1,3)$, strongly' suggest that peripheral arteriolar tone is increased throughout the body just as it is in "essential" hypertension.

Evidence has been obtained that, following constriction of the aorta in animals, hypertension in the upper half of the body occurs only when the constriction is above the orifices of renal vessels $(31,32,33)$. The inference is, of course, that hypertension is due to interference with the renal blood supply as is the case when the renal arteries themselves are constricted. It has also been shown in dogs that increase in tone of the peripheral arterioles takes place under these circumstances in the lower as well as in the upper extremities (34). Although the pulse pressure is very small in the femoral arteries of dogs whose aortas have been constricted above the renal vessels, diastolic pressure may be higher than it was before the aorta was constricted.

Constriction of the renal arteries in dogs, rabbits and monkeys regularly gives rise to increase in diastolic pressure throughout the body. It now appears that in dogs, in the same way, constriction of the aorta above, but not below the orifice of the renal vessels, also gives rise to an increase in diastolic pressure both in the upper and lower extremities. The present observations in patients show that the increase in diastolic pressure often occurs in the legs as well as in the arms in coarctation of the aorta. Elevation of diastolic arterial pressure does not then depend upon some local or mechanical disturbance, but upon a systemic reaction of the arterioles and in this respect resembles that which follows constriction of the aorta above the renal vessels in dogs and constriction of the renal arteries themselves.

Evidence not entirely in accord with this interpretation of the facts exists. For one thing, individuals suffering from coarctation of the aorta rarely, if ever, develop renal insufficiency in the common sense of the term. Their death is commonly due to heart failure or apoplexy and not to renal failure. The recent clear demonstration that renal blood flow is markedly reduced in patients with coarctation of the aorta furnishes grounds for the belief that associated arterial hypertension is renal in origin (35). There are also the studies of Levy and Blalock (36) and, more recently, those of Brotchner (37) suggesting that the proportion of the total blood flow intercepted by constriction of the aorta is important in the development of hypertension. Brotchner's study was, however, carried out only within a period of 40 minutes after constriction and may have little relation to subsequent events. This temporary elevation of pressure was shown in 1931 by Barcroft (38) to be practically abolished by shutting off the return flow from the inferior vena cava and presumably had to do with redistribution of blood. It is possible, also, that elevation of diastolic pressure in the lower extremities may depend upon the belated delivery of blood to this region because of its circuitous route. The degree of delay (roughly 0.05 to 0.07 second) of the maximal pressure, as measured in Case 2 and 3, would hardly seem to account for the observed increase in minimal pressure.

\section{SUMMARY AND CONCLUSIONS}

1. Review of the knowledge of levels of arterial pressure in 217 cases of coarctation of the aorta makes untenable the assumption that increase in peripheral resistance is situated in the upper half of the body only.

2. In two of three cases of coarctation of the aorta, diastolic pressure has been shown by intraarterial measurement to be elevated above $100 \mathrm{~mm}$. $\mathrm{Hg}$ in the femoral, as well as in the radial arteriés. This is interpreted as evidence of general increase in arteriolar tone throughout the body.

3. In so far as the distribution of peripheral arteriolar resistance is concerned, arterial hypertension in coarctation of the aorta does not differ from the common forms of arterial hypertension.

\section{BIBLIOGRAPHY}

1. Lewis, T., Material relating to coarctation of the aorta of the adult type. Heart, 1931-33, 16, 205.

2. King, J. T., Jr., The blood pressure in stenosis at the isthmus (coarctation) of the aorta; case reports. Ann. Int. Med., 1937, 10, 1802.

3. Blumgart, H. L., Lawrence, J. S., and Ernstene, A. 
C., The dynamics of the circulation in coarctation (stenosis of the isthmus) of the aorta of the adult type. Arch. Int. Med., 1931, 47, 806.

4. Prinzmetal, M., and Wilson, C., The nature of the peripheral resistance in arterial hypertension with special reference to the vasomotor system. J. Clin. Invest., 1936, 15, 63.

5. Pickering, G. W., The peripheral resistance in persistent arterial hypertension. Clin. Sc., 1935-6, 2, 209.

6. Railsbeck, O. C., and Dock, W., Erosion of the ribs due to stenosis of the isthmus (coarctation) of the aorta. Radiology, 1929, 12, 58.

7. Spier, L. C., Wright, I. S., and Saylor, L., A new method for determining circulation time throughout the vascular system. Am. Heart J., 1936, 12, 511.

8. Appelbaum, E., and Kalkstein, M., Coarctation of the aorta ; report of a case with associated anomalies. Ann. Int. Med., 1938, 12, 550.

9. Barsantini, J. C., and Bazzano, J. J., Estnosis del Istmo de la Aorta. Arch. Urug. de Med. cir. y Especialid, 1938, 13, 448.

10. Benkowitz, K. B., and Hunter, W. C., Combined infantile and adult coarctation of aorta with coincident occlusion of vena cava superior. Am. J. Path., 1937, 13, 289.

11. Gitlow, S., Coarctation of aorta with report of a living case. N. Y. State Med. J., 1937, 37, 155.

12. Goodson, W. H., Coarctation of the aorta. A report of two unusual cases. New Eng. Med. J., 1937, 216, 339.

13. Hills, R. G., Coarctation of the aorta with unequal blood pressure in the arms. Bull. Johns Hopkins Hosp., 1938, 62, 475.

14a. Klemola, E.,1 Aortan isthmusstenooseista. Duodecim, 1937, 53, 1139.

b. Klemola, E., 1 Uber familiares Auftreten von Isthmusstenose der Aorta. Acta Med. Scandinav., 1939, 98, 355.

15. McNair, J. S., Coarctation of the aorta; report of a case. Chinese Med. J., 1938, 54, 331.

16. Parker, R. L., and Dry, T. J., Coarctation of the aorta at an unusual site associated with congenitally bicuspid aortic valve. Am. Heart J., 1938, 15, 739.

17. Regester, R. P., and Innes, M. B., Spontaneous rupture of the aorta with hemopericardium caused by coarctation. Am. Heart J., 1938, 15, 365.

18. Ernstene, A. C., and Robins, S. A., Roentgenologic diagnosis of stenosis of the descending arch (coarctation) of the aorta. Am. J. Roentgenol., 1931, $25,243$.

19. Rooke, E. J., Early occurrence of high blood pressure in coarctation of the aorta. Brit. Med. J., 1938, 1, 564.

20. Sheldon, W., Coarctation of the aorta. Proc. Roy. Soc. Med., 1932-33, 26, 154.

1 Both of these papers refer to the same four cases, two pairs of brothers.
21. Venzoni, M., Contributo allo studio della atresia congenita dell'aorta. Arch. Ital. di Anat. e Istol. Path., 1938, 8, 236.

22. Walker, J. B., and Livingstone, F. D. M., Coarctation of the aorta; report on 2 cases. Lancet, 1938, 2,660 .

23. Wechsler, H. F., and Gustafson, E., Coarctation of the aorta (adult type) : congenital bicuspid aortic valve; subacute bacterial endocarditis. Am. Heart J., 1937, 14, 107.

24. Weinberg, T. B., and Gartenlaub, C., Coarctation of the aorta, three cases with necropsy findings in one. Radiology, 1938, 31, 445.

25. Wilkinson, K. D., Two cases of coarctation of the aorta. Proc. Roy. Soc. Med., 1932-33, 26, 1537.

26. Wolke, K., Two cases of coarctation (stenosis of the isthmus) of the aorta. Acta Radiol., 1937, 18, 319.

27. Hamilton, W. F., Brewer, G., and Brotman, I., Pressure pulse contours in the intact animal. I. Analytical description of a new high-frequency hypodermic manometer with illustrative curves of simultaneous arterial and intracardiac pressures. Am. J. Physiol., 1934, 107, 427.

28. Page, I. H., The effect of chronic constriction of the aorta on arterial blood pressure in dogs: an attempt to produce coarctation of the aorta. Am. Heart J., 1940, 19, 218.

29. Woodbury, R. A., Murphey, E. E., and Hamilton, W. F., Blood pressures in aortic coarctation: study of pulse contours taken by the direct method. Arch. Int. Med., 1940, 65, 752.

30. Stewart, H. J., and Bailey, R. L., Jr., The cardiac output and other measurements of the circulation in coarctation of the aorta. J. Clin. Invest., 1941, 20, 145.

31. Goldblatt, H., and Kahn, J. R., Experimental hypertension: constriction of aorta at various levels. J. A. M. A., 1938, 110, 686.

32. Rytand, D. A., Pathogenesis of arterial hypertension in coarctation of the aorta. Proc. Soc. Exper. Biol. and Med., 1938, 38, 10.

33. Rytand, D. A., The renal factor in arterial hypertension with coarctation of the aorta, J. Clin. Invest., 1938, 17, 391.

34. Steele, J. M., Effect of partial clamping of the aorta in dogs upon diastolic pressure in carotid and femoral arteries. Proc. Soc. Exper. Biol. and Med., 1939, 41, 86.

35. Friedman, M., Selzer, A., and Rosenblum, H., The renal blood flow in coarctation of the aorta. J. Clin. Invest., 1941, 20, 107.

36. Levy, S. E., and Blalock, A., Fractionation of output of heart and of oxygen consumption of normal unanesthetized dogs. Am. J. Physiol., 1937, 118, 368.

37. Brotchner, R. J., Hypertension from obstruction of the aorta. Proc. Soc. Exper. Biol. and Med., 1939, 40, 264.

38. Barcroft, H., Cardiac output and blood distribution. J. Physiol., 1931, 71, 280. 